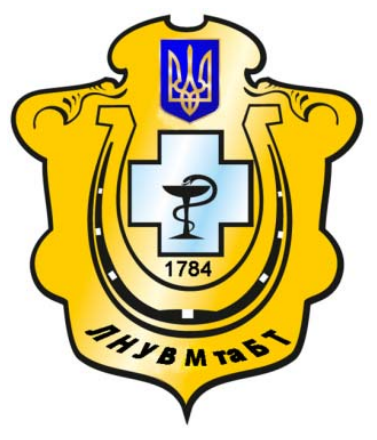

Науковий вісник Львівського національного університету ветеринарної медицини та біотехнологій імені С.3. Гжицького

Scientific Messenger of Lviv National University of Veterinary Medicine and Biotechnologies named after S.Z. Gzhytskyj

doi:10.15421/nvlvet7608

ISSN 2519-2701 print

ISSN 2518-1327 online

http://nvlvet.com.ua/

УДК 336.64

\title{
Шляхи вдосконалення процесу управління оборотними коштами
}

\author{
Я.В. Григор'єва \\ yarynka_g@ukr.net \\ Львівський національний університет імені Івана Франка, \\ вул. Коперника, 3, м. Львів, 79005, Украӥна
}

\begin{abstract}
Стаття присвячена дослідженню значення оборотних коштів для діяльності підприємства. У статті досліджено сутність поняття «оборотні кошти», особливості його управління та основні фактори, що впливають на їх формування. Проаналізовано вплив зовнішніх і внутрішніх факторів на рівень оборотних коштів підприємства. Розглянуто методи управління їх елементами в сучасних умовах для здійснення всебічного аналізу ефективності використання оборотних засобів, щзо дозволить визначити шляхи підвищення їх використання. Запропоновано та обтрунтовано заходи для підвищення ефективності використання оборотного капіталу для успішного розвитку підприємств на основі вдосконалення управління оборотними активами у нестійкому ринковому середовищі.

Ключові слова: оборотні кошти, прочес управління, методи управління, дебіторська заборгованість, запаси.
\end{abstract}

\section{Пути совершенствования процесса управления оборотными средствами}

\author{
Я.В. Григорьева \\ yarynka_g@ukr.net \\ Львовський национальный университет имени Ивана Франко, \\ ул. Коперника, 3, Львов, 79005, Украина
}

\begin{abstract}
Статья посвящеена исследованию значения оборотных средств для деятельности предприятия. В статье исследована сущность понятия «оборотные средства», особенности его управления и основные факторы, влияющие на их формирование. Проанализировано влияние внешних и внутренних факторов на уровень оборотных средств предприятия. Рассмотрены методы управления их элементами в современных условиях для осуществления всестороннего анализа эффективности использования оборотных средств, что позволит определить пути повышения их использования. Предложены и обоснованы меры по повышению эффективности использования оборотного капитала для успешного развития предприятий на основе совершенствования управления оборотными активами в неустойчивом рыночной среде.
\end{abstract}

Ключевые слова: оборотные средства, процесс управления, методы управления, дебиторская задолженность, запасы.

\section{Ways to improve working capital management process}

\author{
Y. Grygorieva \\ yarynka_g@ukr.net
}

Ivan Franko Lviv National University,

Kopernyka Str., 3, Lviv, 79005, Ukraine

Article investigates the importance of working capital to the enterprise. In the article the essence of the concept of «working capital», especially its management and main factors influencing their formation. Clarified the economic essence of the working

\section{Citation:}

Grygorieva, Y. (2017). Ways to improve working capital management process. Scientific Messenger LNUVMBT named after S.Z. Gzhytskyj, 19(76), 3942 . 
capital funds that offer their own definition of this notion that more fully disclose the economic nature of working capital and gives an opportunity to separate them from other concepts. The influence of external and internal factors on the level of working capital business. The methods of control elements in modern terms, to implement the comprehensive analysis of efficiency of working capital, which will identify ways to increase their use. Recommended system of indicators for the implementation of the comprehensive analysis of efficiency of use of working capital that would identify ways to improve their use. Equally important in the management of working capital is accounts receivable management, if the company will follow our suggested ways to manage receivables that will be able to reduce the outflow of working capital and reduce the risk of doubtful and bad debts. Proposed and justified measures to improve the efficiency of working capital for the successful development of enterprises through improved management of current assets in a volatile market environment.

Key words: werewolf koshti, process management, methods of management, debitor's zaborgovinst, stock.

\section{Вступ}

У сучасних умовах господарювання кожне підприємство робить головний акцент на вирішення питань стабільності функціонування та максимізації прибутку. Тому на перший план виходить питання управління оборотними активами як основи виробничої діяльності. Для того щоб досягти поставлених цілей, потрібна чітко збудована, обгрунтована і ефективна фінансова політика управління активами підприємства, в яких значну роль відіграють оборотні кошти. Брак оборотних коштів ставить підприємство на грань банкрутства, що змушує задуматись над удосконаленням системи управління ними.

\section{Матеріал і методи досліджень}

Вагомий внесок зробили такі дослідники як С.М. Онисько, П.М. Марич, вони досліджували джерела фінансування оборотних коштів.

В.В. Ковальов проаналізував моделі управління залежно від їх формування. Також питання моделювання процесів управління оборотними коштами підприємства розглядаються у працях В.I. Борзенка, О.О. Демьохіна та інших.

Мета статті полягає у визначенні можливих шляхів підвищення ефективності використання оборотних коштів на промисловому підприємстві.

\section{Результати та їх обговорення}

Діяльність суб'єктів господарювання щодо створення та реалізації продукції здійснюється через поєднання основних виробничих фондів, оборотних засобів і самої праці. Оборотні кошти - це найбільш мобільна частина капіталу, від стану і раціонального використання якого багато в чому залежить результат господарської діяльності та фінансове становище підприємства. Відомо, що існує пряма залежність між результатами діяльності підприємства та системою управління, формуванням та використанням оборотних коштів. Варто зазначити, що система управління має свої особливості (Azarenkova et al., 2009).

Першим кроком в системі управліннями оборотними коштами варто назвати їх структурний аналіз та динаміку, що дозволяє визначити, яка тенденція: збільшення чи зменшення оборотних коштів та визначити оптимальний обсяг і структуру оборотних коштів.

Адже правильність розміщення оборотних коштів має свої особливості як в окремих галузях, так і на окремих підприємствах.
Наступним кроком є аналіз показників ефективності використання оборотних коштів, а також чинників, які впливають на них. Не варто залишати поза увагою той факт, що саме завдяки нормуванню відбувається значна економія ресурсів, що призводить до зменшення витрат та ризиків. При управлінні потрібно приділити значну увагу зовнішнім та внутрішнім чинникам.

Якщо розглядати операційний цикл, то у своєму русі оборотні кошти послідовно проходять три стадії: заготовчу, виробничу та реалізаційну.

Заготовча стадія - «гроші - виробничі запаси» охоплює період, необхідний для створення виробничих запасів. Оборотні кошти на цій стадії у вигляді грошей використовують для закупівлі сировини, матеріалів та інших предметів праці.

Виробнича стадія - «виробничі запаси - готова продукція» - починається 3 отримання предметів праці та завершується відправленням готової продукції на склад підприємства.

Оборотні кошти на цій стадії мають вигляд предметів праці, незавершеної та готової продукції (Nesterenko, 2009).

Стадія реалізації - «готова продукція - гроші» починається з надходження готової продукції на склад підприємства i завершується отриманням виручки від реалізації продукції. Оборотні кошти на цій стадії перебувають у вигляді готової продукції та грошей. Лише після того, як товарна форма вартості зробленої продукції перетвориться в грошову, авансовані кошти відновлюються за рахунок частини виторгу, що надійшов від реалізації продукції. При цьому за необхідності на розширення оборотних коштів може бути спрямована частина отриманого прибутку.

У такому випадку в наступних циклах братиме участь більший обсяг оборотних коштів. Важливо розуміти, що грошова форма, якої набувають оборотні кошти на третій стадії їхнього кругообігу, одночасно $є$ і початковою стадією операційного циклу, а отже, важливим напрямком підвищення ефективності використання оборотних коштів є удосконалення їх розподілу за стадіями кругообігу та зниження питомої ваги фондів оберту (Filimonenkov, 2002).

Таким чином для кожної окремо узятої стадії можна запропонувати такі заходи:

- на стадії створення виробничих запасів: ліквідація наднормативних запасів матеріалів; удосконалення нормування; поліпшення організації постачання, у тому числі через установлення чітких договірних умов і забезпечення їх виконання, оптимальний вибір постачальників, налагодження роботи транспорту; поліпшення організації складського господарства; 
- на стадії виробництва: упровадження прогресивної техніки та технології, зокрема безвідходної та маловідходної; розвиток стандартизації й уніфікації; удосконалення форм організації виробництва; удосконалення системи економічного стимулювання; заохочення більш економного використання сировинних та паливно-енергетичних ресурсів; удосконалення використання основних фондів, насамперед, їх активної частини;

- на стадії реалізації готової продукції: раціональна організація збуту готової продукції; застосування прогресивних форм розрахунків; своєчасне оформлення документації та прискорення іiі руху; дотримання договірної та платіжної дисципліни (Hrynchutskyi, 2010).

Зазначені заходи дозволять прискорити оборотність оборотних коштів, що в свою чергу надасть можливість збільшити обсяги виробництва та реалізації продукції без додаткових фінансових вливань . Однак у сучасних умовах господарювання кожне підприємство робить головний акцент на вирішенні питань стабільності функціонування та максимізації прибутку.

Визначення потреби в оборотних коштах здійснюється через їх нормування. На процес нормування оборотних коштів впливає багато факторів.

На підприємствах виробничої сфери до них належать: кількість постачальників, строки поставки, розмір транзитних партій, кількість найменувань матеріальних цінностей, форми розрахунків за матеріальні цінності, тривалість виробничого циклу, характер розподілу витрат протягом виробничого циклу, номенклатура випущеної продукції, кількість споживачів готової продукції, їх віддаленість, призначення продукції, умови iї транспортування, форми розрахунків за відвантажену продукцію (Poddierohin et al., 2006).

Враховуючи досить широкий перелік факторів впливу, для удосконалення процесу нормування можна запропонувати такі заходи:

1) вчасне урахування всіх техніко-технологічних та організаційних змін;

2) постійний перегляд норм та нормативів;

3) автоматизація системи нормування (за можливості).

Визначення джерел фінансування оборотних коштів є важливою ділянкою роботи підприємства. За джерелами фінансування оборотні кошти поділяються на власні, залучені та запозичені. Недостатність джерел фінансування оборотних коштів призводить до поточних фінансових ускладнень. Але наявність зайвих джерел фінансування навпаки сприяє створенню наднормових запасів товарно-матеріальних цінностей, відволіканню (Peltek and Pysarenko, 2010).

Варто пам'ятати, що ефективність формування та використання оборотних коштів зумовлена певними особливостями управління їх основними структурними елементами: запасами, дебіторською заборгованістю та грошовими коштами.

Основними методами контролю запасів є такі :

- Нормування, що включає в себе аналітичний, коефіцієнтний i прямий методи розрахунку оптимального рівня запасів;
- Контроль запасів, що передбачає використання методів ABC і XУZ та методу економічно обгрунтованих потреб.

Вибір того чи іншого методу проведення аналізу оборотних коштів на підприємстві, дозволяє отримувати достовірну та об'єктивну інформацію про хід справ на даному підприємстві. Визначення величини оборотних коштів за аналітичним методом передбачає грунтовний аналіз фактичних запасів, коригування їх величини та вилучення надлишків, якщо вони є на підприємстві.

Коефіцієнтний метод полягає у визначенні чинності нормативів власних оборотних коштів на початку розрахункового періоду, з урахуванням показників виробництва цього періоду.

Метод прямого розрахунку, дозволяє визначити фактичну потребу підприємства запасах на встановлений період.

Метод економічно обгрунтованих потреб це мінімізація сукупних операційних витрат зі закупівлі та збереженні запасів на підприємстві. Він дає можливість розрахувати витрати по зберіганню їх.

Метод $\mathrm{ABC}$ він $\epsilon$ найпростішим способом управління запасів і розподіляє запаси на три категорії.

А - найважливіші, які включають 20\% запасів і $80 \%$ - продажу.

В - важливі, що поділяють на $30 \%$ запасів і 15\% продажу.

С - менш важливі, де 50\% запасів і 5\% - продажу. Особливість цього $є$ те, що порівняно мала група запасів може мати найбільшу вартість.

Метод XУZ полягає у поділі запасів залежно від попиту і точності прогнозування величини споживання товарів. Цей метод оснований на розподілі ресурсів підприємства на категорії.

1) $\mathrm{X}$ - це стабільна величина споживання і висока точність прогнозу. Значення коефіцієнта варіації в інтервалі від 0 до $10 \%$.

2) У - це вже визначена величина споживання, відповідно до чинників,які на них впливають. Значення коефіцієнта від 10 до $25 \%$.

3) $\mathrm{Z}$ - це малий рівень споживання товарів і невисокою точністю прогнозування. Значення коефіцієнта понад 20\%.

Згідно 3 дослідженнями Стерлігової А.М., яка вважає,що найефективнішим використанням методів відбулось б при їх об'єднанні АВС та XУZ, тому що при ї зіставленні можна отримати цінні інструменти планування та контролю для системи постачання в цілому та управління запасами зокрема.

Для забезпечення постійної наявності оборотних коштів і платоспроможності підприємства дуже важливе значення має не лише їх обсяг але i ефективність управління дебіторською заборгованістю. А останнє в свою чергу залежить від способу управління дебіторською заборгованістю (Povazhnyi et al., 2008).

На наш погляд слід дотримуватись таких способів управління дебіторською заборгованістю:

1. Створення клірингових центрів, які здійснювали операції, що включають в себе збір інформації щодо 
результатів торгівлі, на основі яких будуть здійснюватись фінансові операції;

2. Продаж заборгованості, що може бути здійснено через факторинг, при купівлі грошових вимог постачальника до покупців за визначену винагороду;

3. Застава.

Якщо підприємство буде дотримуватись вище зазначених способів управління дебіторською заборгованістю, то буде мати можливість зменшити відтік оборотних коштів та зменшити ризики виникнення сумнівної та безнадійної дебіторської заборгованості. Але це не означає, що не потрібно використовувати інші, не менш важливі методи.

Отже, як нестача обортних коштів, так і їх надлишок чинять значний вплив на підприємство, спричиняючи збої у виробництві чи постачання сировини, чим зменшують очікуваний прибуток (Hetman and Shapoval, 2010).

\section{Висновки}

Оборотні кошти промислових підприємств займають значну частку в загальній сумі активів. Наявність у підприємства достатнього обсягу оборотних коштів та їх оптимальна структура - необхідні передумови для його нормального функціонування та фінансової стійкості в умовах ринкової економіки. Тож ефективне використання оборотних коштів відіграє значну роль у досягненні підприємством високих результатів діяльності. Сформульована система управління оборотними коштами дозволить здійснювати ефективний аналіз та визначити оптимальний обсяг і структуру оборотних коштів. На основі визначення показників ефективності використання оборотних коштів розрахувати резерви їх зростання та норматив, який забезпечить ефективне функціонування за мінімального обсягу оборотних коштів.

Значну увагу слід приділяти прискоренню оборотності оборотних активів, яке можливе за рахунок різного роду заохочень для клієнта купувати продукцію та залучення на підприємство комерційного кредиту.
Отже, врахування особливостей управління оборотними коштами на підприємстві сприятиме підвищенню ефективності його функціонування, збільшення рівня ліквідності, платоспроможності та фінансової стійкості.

\section{Бібліографічні посилання}

Poddierohin, A.M., Bilyk, M.D., Buriak, L.D. (2006). Finansy pidpryiemstv: pidruchnyk [6-te vyd., pererob. ta dopov.]. K.; KNEU (in Ukrainian).

Azarenkova, H.M., Zhuravel, T.M., Mykhailenko, R.M. (2009). Finansy pidpryiemstv: navchalnyi posibnyk. [3-tie vyd., vypravl. i dop.]. K.: Znannia-Pres (in Ukrainian).

Hetman, O.O., Shapoval, V.M. (2010). Ekonomika pidpryiemstva: navchalnyi posibnyk. K.: Tsentr uchbovoi literatury (in Ukrainian).

Peltek, L.V., Pysarenko, S.M. (2010). Metodolohichni aspekty formuvannia systemy upravlinnia oborotnymy aktyvamy pidpryiemstva. Visnyk Zaporizkoho natsionalnoho universytetu. 1(5), 43-49 (in Ukrainian).

Povazhnyi, O.S., Kramzina, N.O., Kvasha, Yu.V. (2008). Osoblyvosti vyznachennia sutnosti ta skladu poniattia «oborotni aktyvy». Ekonomichnyi prostir. 12/2, 41-52 (in Ukrainian).

Filimonenkov, O.S. (2002). Finansy pidpryiemstva : navchalnyi posibnyk. K.: Elha, Nika-Tsentr (in Ukrainian).

Pokropyvnyi, S.F. (2001). Ekonomika pidpryiemstva: pidruchnyk. K.: KNEU (in Ukrainian).

Nesterenko, S.S. (2009). Oborotni koshty v umovakh formuvannia rynkovoi ekonomiky. Naukovyi visnyk Akademii munitsypalnoho upravlinnia. 7, 49 (in Ukrainian).

Hrynchutskyi, V.I. (2010). Ekonomika pidpryiemstva: navchalnyi posibnyk. K.: Tsentr uchbovoi literatury (in Ukrainian).

Стаття надійшла до редакиії 1.03.2017 